\title{
Tantangan dan Peluang Pemerintah Daerah dalam Penanggulangan Kemiskinan
}

\author{
Fadel Muhammad \& Mahmudi
}

The problem of poverty and unemployment become tremendous challenge to be solved by local government in this autonomy and fiscal decentralization era. Through local autonomy and decentralization, there are obviously greater opportunities to localize the problem of poverty and to take action based on local condition and local contingency factors. Poverty alleviation program initiated by local govemment should be oriented to be more humanistic with dignity approach, that is taking people in poor as a subject to be enhanced and entrusted to be able to escape from their poverty problem. Through the concept of self-help community, the problem of poverty can be eradicated more effective. The big challenge faced by local government conceming to the poverty alleviation program is to develop strong political and economic democration in a local context. There are at least six pillars that need deep attention to be improved and enhanced, i.e. education, people income, health, regulation and law enforcement, public service infrastructure, and institutional building.

Kata kunci: kemiskinan, wirausaha, pemberdayaan, dan Kemitraan.

$D$ emberantasan atau pengurangan kemiskinan (poverty alleviation) merupakan agenda yang sangat penting dalam perencanaan program dan kebijakan pemerintah pusat maupun daerah. Hal ini karena tujuan tertinggi penyelenggaraan pemerintahan adalah untuk mewujudkan kesejahteraan masyarakat.(social welfare). Kesejahteraan masyarakat tidak akan pernah tercapai selama bangsa kita masih dihadapkan pada masalah tingginya tingkat kemiskinan, pengangguran, dan disparitas ekonomi.

Terjadinya kemiskinan massal yang dibarengi dengan ancaman kelaparan dan gizi buruk; meningkatnya disparitas regional, nasional, dan internasional; penggunaan sumber daya yang eksploitatif dan tidak memikirkan aspek kesinambungan antargenerasi; teknologi yang tidak sesuai dengan kebutuhan pembangunan; proses produksi dan konsumsi yang tidak ramah lingkungan; inflasi dan stagnasi yang berkepanjangan; ketergantungan negara berkembang terhadap negara maju; banyaknya kelompok yang terbanting oleh krisis ekonomi sementara kelompok lain kelebihan kekayaan, menunjukkan adanya suatu masalah besar dalam sistem perekonomian suatu negara.

Selama ini, perhatian utama indikator kemajuan perekonomian suatu negara atau daerah diukur dari aspek pendapatan yang bersifat kuantitatif-keuangan, misalnya tingkat pertumbuhan ekonomi (economic growth) yang diproksikan dengan ukuran Pendapatan per Kapita (Income per Capita), 
Gross National Product (GNP), Gross Domestic Product (GDP) atau Produk Domestik Regional Bruto (P.DRB), dan sebagainya. Ukuran pertumbuhan ekonomi tersebut memang penting dan tidak bisa diabaikan, tetapi terlalu bertumpu pada pertumbuhan ekonomi saja dan mengabaikan ukuran kinerja lain, sangat mungkin terjadi distorsi dalam penilaian kesuksesan upaya pembangunan untukmencapai kesejahteraan bangsa. Agar lebih adil, hendaknya ukuran keberhasilan pembangunan juga ditekankan pada aspek penurunan jumlah (angka) kemiskinan. Karena tingkat pertumbuhan ekonomi tinggi yang dibarengi dengan tingkat kemiskinan yang tinggi pula pada dasarnya tidak akan memberikan manfaat yang berarti bagi kesejahteraan rakyat secara keseluruhan. Dalam hal ini perlu dilakukan perubahan paradigma dalam menilai keberhasilan pemerintahan dalam penyelenggaraan pembangunan, yaitu perubahan dari berorientasi pertumbuhan ekonomi (economic growth minded) menjadi berorientasi pengurangan kemiskinan (poverty alleviation minded). Keberhasilan pembangunan hendaknya dilihat dariseberapa besar berkurangnya masyarakat yang miskin, bukan sekadar seberapa besar bertambahnya orang kaya.

Dalam konteks pemberantasan kemiskinan, Prof. Gunawan Sumodiningrat (2005) juga menyatakan perlunya paradigma baru' dalam upaya penanggulangan kemiskinan, yaitu paradigma pembangunan manusia (human development) yang difokuskan pada tiga upaya, yaitu:

- Pengembangan kapasitas (capacity building);

- Pemberdayaan masyarakat (community empowerment); dan

- Pengembangan masyarakat (community development)

Terkait dengan tiga agenda tersebut, peran pemerintah yang utama adalah sebagai fasilitator dalam menciptakan iklim. usaha yang kondusif (conducive business climate) dan menumbuhkembangkan lingkungan yang mampu mendorong pengembangan usaha ekonomi produktif masyarakat miskin (enabling environment).

Pemikiran Prof. Gunawan Sumodiningrat secara filosofis menyiratkan kepada pemerintah tentang perlunya dilakukan pemberantasan kemiskinan secara manusiawi, bermartabat, beradab, dan berbudaya. Sementara, secara teknisoperasional pemerintah perlu melakukan kebijakan, strategi, dan program penanggulangan kemiskinan yang strategik, taktis, efisien (tepat cara), dan efektif (tepat sasaran) dengan memperhatikan semua aspek yang mempengaruhi terjadinya kemiskinan. Semua aspek tersebut perlu dikelola melalui tata kelola pemerintahan yang baik (good governance), yaitu memperhatikan prinsip transparansi, akuntabilitas, dan partisipasi publik. ${ }^{2}$

Penanggulangan kemiskinan harus dilakukan secara manusiawi, bermartabat, beradab, dan berbudaya, yaitu dengan tidak menjadikan masyarakat miskin sebagai objek semata-mata. Masyarakat miskin hendaknya diperlakukan sebagai subyek yang aktif dan dipercaya mampu untuk membebaskan dirinya dari beban kemiskinan sehingga pada akhimya mereka dapat mengentaskan kemiskinannya sendiri (self-help community). Hal ini juga berarti pemerintah hendaknya tidak langsung memberikan ikan kepada masyarakat

1 Lihat Gunawan Sumodiningrat (2005) Otonomi Daerah Dalam Penanggulangan Kemiskinan: Upaya-Upaya Pengurangan Pengangguran dan Pemberdayaan Usaha Mikro di Tingkat Lokal, Jakarta.

2 lbid 
miskin, tetapi memberikan pancing, jala, perahu, atau kapal kepada mereka. Tentunya pemerintah tidak cukup memberikan sarana atau peralatan, tetapi juga melakukan capacity building dengan membangun skill dan kemampuan teknis masyarakat termasuk penggunaan teknologi.

Penanggulangan kemiskinan tidak dapat dilakukan sekadar dengan cara membagi-bagikan uang kepada masyarakat miskin secara langsung. Bantuan Langsung Tunai dapat diberikan hañya untuk jangka pendek. Sementara, penangggulangan kemiskinan dalam jangka panjang dan berkesinambungan diperlukan pendekatan yang tidak bersifat pemberian tunai, tetapi dalam bentuk bantuan pembiayaan dan pembangunan kapasitas. Perlu disadari bahwa terdapat dua karakteristik orang miskin, yaitu: ketiadaan uang (moneylessness), dan ketidakberdayaan (powerlessness). ${ }^{3}$ Kemiskinan karena ketiadaan uang disebabkan karena orang miskin tidak memiliki alat tukar dasar (lack of medium of exchange) yang cukup, yaitu uang untuk memenuhi kebutuhan paling dasarnya, seperti: pangan, sandang, papan, kesehatan, dan pendidikan. Masyarakat yang tingkat pendapatannya sangat rendah sehingga tidak mampu memenuhi kebutuhan dasarnya juga masuk dalam kategori miskin karena ketidakcukupan uang.

Kemiskinan karena ketidakberdayaan (powerlessness) disebabkan karena mereka tidak memiliki kekuatan (lack of power), yaitu kekuatan dalam hal: 1) melakukan kegiatan produktif, 2) menjangkau akses sumber daya sosial dan ekonomi, 3) menentukan nasibnya sendiri, 4) melawan perlakuan diskriminasi yang dialaminya, 5) memperjuangkan hak-hak hidup dan hak sosialnya, dan 6) membebaskan dirinya dari mental dan budaya miskin serta senantiasa merasa memiliki martabat dan harga diri yang rendah (inlander, kelas kuli, jongos, PRT, dan sebagainya).

Sejalan dengan hal di atas, Prof. Gunawan Sumodiningrat menunjukkan bahwa kemiskinan di Indonesia memiliki empat dimensi pokok, yaitu:

1. Kurangnya kesempatan (lack of opportunity)

2. Rendahnya kemampuan (lack of capability).

3. Rendahnya partisipasi (lack of participation)

4. Kurangnya jaminan sosial (lack of social security)

Kurangnya kesempatan terkait dengan kemiskinan struktural yang terjadi karena tidak ada atau rendahnya kesempatan berusaha, termasuk kesempatan untuk memperoleh modal dan sumber pembiayaan, kebijakan pembangunan ekonomi yang tidak memihak rakyat kecil, dan kesempatan kerja yang terbatas. Selain faktor kesempatan, kemiskinan juga terjadi karena rendahnya kemampuan (capability), ketrampilan (skil), dan pengetahuan (knowledge) yang menyebabkan mereka sangat sulit terserap pasar tenaga kerja. Sementara, untuk berusaha juga menghadapi kesulitan karena tidak memiliki ketrampilan dan pengetahuan yang memadai. Kemiskinan juga bisa terjadi karena rendahnya partisipasi masyarakat dalam pembuatan keputusan dan kebijakan publik terkait dengan pembangunan ekonomi dan pemecahan masalah kemiskinan. Dan terakhir, kemiskinan juga dapat disebabkan karena kurangnya jaminan sosial. Masyarakat yang masuk dalam kategori

${ }^{3}$ Lihat Dale A. Tussing (1975) Poverty in a Dual Economy, New York: ST Martin's Press. 
tidak atau kurang cukup uang masih dapat diselamatkan dari garis kemiskinan apabila terdapat program kesejahteraan (welfare program) dan jaminan sosial, misalnya asuransi kesehatan, kompensasi BBM, kompensasi pengangguran, subsidi, pensiun, dan sebagainya. Dalam hal ini sebenarnya pemerintah juga telah melakukan berbagai langkah dan program jaring pengaman sosial (social security net) untuk memberikan jaminan sosial kepada masyarakat miskin, misalnya: program IDT, PDMDKE, PEMP, P3DT, P4K, subsidi BBM yang kemudian dialihkan menjadi Bantuan Langsung Tunai (BLT), subsidi pupuk, subsidi obat, subsidi pendidikan, dan sebagainya.

\section{Kemiskinan, Otonomi Daerah Dan Desentralisasi Fiskal}

Jika dilihat dari konsepnya, pada dasamya desentralisasi berarti pemecahan administrasi yang terkonsentrasi di pemerintah pusat ke pemerintah daerah. Desentralisasi juga melibatkan terjadinya pendelegasian kekuasaan dari pemerintah pusat ke pemerintahan yang lebih bawah. Namun demikian, desentralisasi harus dibedakan dengan pemindahan tugas kementrian pusat ke daerah, atau delegasi pemerintah pusat ke pemerintah di bawahnya untuk melaksanakan tanggung jawab pemerintah pusat di daerah. Meskipun desentralisasi juga termasuk delegasi, akan tetapi delegasi tersebut ditambah dengan diskresi, yaitu keleluasaan pemerintah bawahan untuk menentukan pilihan kebijakan pembangunan. Desentralisasi juga berarti pembagian kekuasaan teritorial. Desentralisasi mengakibatkan pembagian wilayah teritorial negara menjadi wilayahwilayah yang lebih kecil serta penciptaan institusi politik dan administratif di wilayah tersebut.
Kebutuhan terhadap desentralisasi dalam sistem pemerintahan merupakan kebutuhan yang bersifat universal. Bahkan negara kecil sekalipun membutuhkan desentralisasi dengan tingkat otonomitertentu. Fungsi-fungsi yang harus dilaksanakan oleh negara modem menuntut dilakukannya penyederhanaan praktikadministrasi ke level pemerintah yang lebih bawah, karena pemerintah daerah lebih dekat dengan permasalahan dan masyarakat yang harus dilayani. Desentralisasi merupakan kebutuhan minimal (necessary condition) untuk melakukan pembangunan sosial, ekonomi, dan politik. Apapun ideloginegara yang dianut, tingkat intervensi, dan pendekatan perencanaan pembangunan yang digunakan, pemerintahan dewasa iniperiu "mendaerahkan" beberapafungsipemerintahannya

Desentralisasi sebagai pilihan kebijakan politik menjanjikan beberapa manfaat ${ }^{4}$, antara lain:

1. Secara ekonomi, desentralisasi dapat memperbaiki efisiensi, mengurangi ekonomi biaya tinggi, memperbaiki output, serta pemanfaatan sumber daya manusia secara lebih efektif;

2. Secara politik, desentralisasi dapat memperkuat demokrasi lokal, akuntabilitas, political skill, dan persatuan nasional;

3. Desentralisasi menjadikan pemerintah lebih dekat dengan masyarakat dan mampu memberikan pelayanan publik yang lebih baik, meningkatkan demokrasi lokal, pemerataan dan keadilan ekonomi, mengurangi kemiskinan serta meningkatkan kesejahteraan masyarakat;

4 Lihat Cheema dan Rondinelli (1983) Decentralization and Development: Policy Implementation in Developing Countries, London: Sage Publication in Cooperation with the United Nations Centre for Regional Development. 
4. Desentralisasi juga dapat meningkatkan partisipasi masyarakat, melatih political leadership bagi politisi lokal maupun nasional;

5. Desentralisasi memperbaiki akses masyarakat lokal terhadap lembagalembaga administrasi pemerintahan; dan

6. Desentralisasi dapat mengurangi kemacetan dan keruwetan di pusat, meningkatkan kecepatan dan fleksibilitas pengambilan keputusan dan perbaikan pelayanan publik.

Terdapat dua sasaran penting dalam pelaksanaan desentralisasi, yaituterjadinya peningkatan otonomi dan demokratisasi di pemerintah daerah. Dengan dilakukannya pembagian wilayah teritorial negara ke dalam wilayah pemerintah daerah maka tingkat otonomi masing-masing daerah dapat diukur. Selanjutnya, institusi-institusi di daerah akan dilakukan secara demokrasi, sehingga menjamin pengambilan keputusan di daerah dilakukan sesuai dengan prosedur demokrasi. Bagi pemerintah pusat, manfaat utama desentralisasi adalah untuk: 1) pendidikan politik (political education) masyarakat dan pejabat publik, 2) latihan kepemimpinan (political leadership), dan 3) stabilitas politik (political stability). Sementara itu, bagi pemerintah daerah manfaat desentralisasi adalah: 1) pemerataan pembangunan (equality), 2) kebebasan (otonomi \& diskresi), dan 3) kepekaan (responsiveness) terhadap publik. ${ }^{5}$

Jika dilihat dari perspektif teori pilihan publik dan barang publik, maka deséntralisasi merupakan sarana penting untuk meningkatkan kesejahteraan personal. Menurut pendekatan teori ini, seseorang diasumsikan akan memilih tempat tinggalnya karena membandingkan ketersediaan pelayanan dan sarana publik dengan pajak-pajak atau pungutan yang harus ia tanggung untuk masing-masing wilayah yang berbeda. Dengan membagi negara dalam wilayah-wilayah yang otonom melalui sistem desentralisasi, maka pilihan publik akan semakin besar. Pemerintah daerah dapat memberikan kesempatan yang lebih besar kepada masyarakat untuk menentukan pilihan hidup yang terbaik bagi mereka. Masyarakat dapat langsung menyampaikan-keluhannya apabila mendapatkan pelayanan publik yang kurang memuaskan dari pemerintah daerah setempat. Atau mereka dapat pindah ke kota atau pemerintah daerah lain yang memberikan sarana dan pelayanan publik yang lebih baik dengan tingkat pajak tertentu. Asumsi ini memberikan implikasi penting dalam mendesain sistem pemerintah daerah.

Otonomi daerah dan desentralisasi jika dilihat dari teori pilihan publik dan barang publik ${ }^{6}$ memberikan beberapa manfaat, antara lain:

1. Meningkatkan responsivitas pemerintah daerah terhadap preferensi publik, baik secara kolektif maupun individual.

2. Permintaan terhadap barang publik dapat dipenuhi secara lebih baik.

3. Di sisi penawaran barang publik, dengan dilakukan desentralisasi maka permasalah utama yang dihadapi pemerintah terkait dengan lemahnya efisiensi alokatif dan efisiensi teknis dapat diperbaiki. Dengan semakin meningkatnya efisiensi alokatif dan efisiensi teknis tersebut, maka pemerintah dapat menyediakan barang publik yang lebih baik kualitasnya.

4. Permasalahan terjadinya kesenjangan (gap) yang besar antara teori dan
5 lbid.
6 ibid. 
praktik dapat dijembatani dengan lebih baik. Desentralisasi dapat memperbaiki political wisdom dan kearifan lokal (local wisdom). Dengan dilakukannya desentralisasi, maka terbuka kesempatan yang lebih luas bagi para ilmuwan dan akademisi untuk mengaplikasikan teorinya dalam praktik pemerintahan di daerah.

\section{Otonomi Daerah dan Penanggulangan Kemiskinan}

Salah satu janji desentralisasi dan otonomi daerah adalah menjadikan pemerintah lebih dekat dengan masyarakat dan mampu memberikan pelayanan publik yang lebih baik, meningkatkan demokrasi lokal, pemerataan dan keadilan ekonomi, mengurangi kemiskinan serta meningkatkan kesejahteraan masyarakat. Pelaksanaan otonomi daerah dan desentralisasi fiskal di Indonesia yang dimulai sejak 1 Januari 2001 menghadapi tantangan berat berupatingginya tingkat kemiskinan dan pengangguran akibat krisis moneter (krismon) yang berlanjut ke krisis ekonomi dan politik tahun 1997/1998. Tantangan pemerintah daerah dalam menanggulangi kemiskinan di daerah pada hakikatnya merupakan batu ujian atas pelaksanaan otonomi daerah dan desentralisasi fiskal. Dengan adanya otonomi daerah dan desentralisasi, permasalahan kemiskinan bisa dilokalisir dan kesempatan pemerintah daerah untuk menangani secara langsung masalah ini sangat besar.

Prof. Gunawan Sumodiningrat menyatakan bahwa pembangunan di daerah harus senantiasa diorientasikan kepada pencapaian sasaran penurunan kemiskinan dan pengurangan pengangguran. Caranya adalah melalui perluasan kesempatan kerja (creating opportunity) dan penciptaan lapangan kerja (employment creation). Untuk itu, strateginya dibagi menjadi dua wilayah utama, yaitu: 1) strategi penanggulangan kemiskinan, dan 2) strategi pemberdayaan Usaha Mikro, Kecil, dan Menengah (UMKM).?

Untuk strategi penanggulangan kemiskinan, diperlukan langkah yang bersifat mandiri, meliputi:

1. Penyusunan indikator kemiskinan lokal. Indikator kemiskinan meliputi indikator mikro dan makro. Indikator tersebut diperlukan untuk mengetahui ukuran-ukuran kemiskinan secara tepat, sesuai dengan kondisi lokal dan disepakati oleh masyarakat lokal.

2. Pemetaan penduduk miskin (poverty mapping). Pemetaan penduduk miskin dimaksudkan untuk menghasilkan gambaran yang utuh tentang jenis kelompok masyarakat miskin serta berbagai jenis permasalahan kemiskinan yang utama sesuai dengan indikator kemiskinan mikro yang telah dikembangkan. Hal ini untuk mengetahui potret kemiskinan di daerah secara lebih tepat dan akurat.

Strategi penanggulangan kemiskinan selanjutnya perlu dilaksanakan dalam kerangka peraturan (regulation framework), kerangka anggaran (budget framework), dan kerangka waktu (time framework) tertentu secara tepat. Kerangka peraturan atau regulasi dilakukan melalui pengeluaran produk-produk hukum di daerah yang mampu menciptakan iklim yang kondusif (conducive climate) dan mampu memihak, melindungi, dan memberdayakan masyarakat miskin. Selain itu, diperlukan peraturan daerah yang mampu mewujudkan lingkungan yang mendorong (enabling environment) kemampuan masyarakat miskin

7 Gunawan Sumodiningrat, Ibid. 
dalam upaya menyelesaikan permasalahan kemiskinan secara mandiri, sistemik, dan berkelanjutan. Pemikiran ini sangat tepat di laksanakan oleh pemerintah daerah. Jika pemerintah pusat melalui Undang-Undang telah mewajibkan setiap BUMN untuk menyisihkan sebagian laba bersihnya (kurang lebih $5 \%$ ) untuk pengembangan usaha kecil dan menengah (UKM), maka pemerintah daerah kiranya perlu membuat peraturan daerah (Perda) yang mewajibkan setiap BUMD dan BUMN di daerah menyisihkan sebagian labanya untuk penanggulangan kemiskinan di daerah, yaitu melalui pengembangan UMKM di daerah. Selain itu perlu juga didorong melalui regulasi pemda agar perusahaan-perusahaan swasta yang beroperasi di daerah dapat mengalokasikan anggarannya untuk pengembangan UMKM di daerah. Hal itu juga menjadi salah satu tuntutan perlunya perusahaan melakukan tanggung jawab sosial (social responsibility of business enterprises).

Melalui kerangka anggaran pemerintah daerah perlu mengalokasikan dana pembangunan daerah (APBD) yang mendukung pembiayaan untuk berbagai program dan kegiatan penanggulangan kemiskinan di daerah. Pemerintah daerah perlu membuat APBD yang pro rakyat miskin (pro poor budget) baik secara langsung maupun tidak langsung. Dalam hal ini sasaran dan fokus penanggulangan kemiskinan ditujukan pada upaya pemberdayaan masyarakat, peningkatan kapasitas dan penjaminan sosial. Peningkatan kapasitas masyarakat hendaknya difokuskan pada upaya peningkatan kapasitas usaha ekonomi produktif masyarakat miskin yang berada dalam kelompok usia produktif (15-55 tahun). Untuk kelompok masyarakat miskin di bawah usia 15 tahun perlu dilakukan pro- gram penyiapan sosial melalui program pelayanan dasar melalui pendidikan dasar dan kesehatan. Dalam hal ini, pemerintah daerah harus menjamin kemudahan akses bagi masyarakat miskin untuk memperoleh pendidikan dasar (Wajar 9 tahun) dan kesehatan. Sementara, untuk kelompok usia di atas 55 tahun, pemerintah daerah perlu menyediakan dana untuk perlindungan sosial (social security).

Adapun skema alokasi APBD untuk mendukung program penanggulangan kemiskinan di daerah dapat dilakukan melalui cara-cara berikut:

1. Penyediaan subsidi dana modal bergulir (revolving fund) bagi individu/kelompok masyarakat miskin yang masuk dalam kategori tidak layak secara manajerial (non feasible) dan tidak layak secara keuangan (non bankable).

2. Penyediaan dana pinjaman kredit mikro bagi individu/kelompok masyarakat miskin produktif. Dalam hal ini pemerintah daerah dapat bekerjasama dengan bank-bankumum maupun BPR di daerah.

3. Penyediaan dana operasional untuk mendukung penyaluran skema KUMLTA (Kredit Usaha Mikro Layak Tanpa Agunan Tambahan) di tingkat lokal.

4. Penyediaan tenaga pendamping/ konsultan (fasilitator) baik dalam bentuk Konsultan/Pendamping Usaha Mikro, Kecil, dan Menengah Mitra Bank (pendamping keuangan) maupun Business Development Service (pendamping usaha).

5. Pembiayaan berbagai fasilitas, mediasi, dan advokasi usaha untuk mendukung berjalannya forum kerjasama dan kemitraan usaha antara pelaku usaha mikro dengan pelaku usaha kecil, menengah, dan besar. 
Śkema alokasi APBD untuk menanggulangi kemiskinan di daerah tersebut di atas sangat penting dan perlu direalisasikan oleh pemerintah daerah. Dalam tahap implementasi di lapangan, agar tidak terjadi penyimpangan maka pemerintah daerah perlu menyiapkan tim pemantauan dan pengawasan atas program penanggulangan kemiskinan di daerah.

\section{Kunci Penanggulangan Kemiskinan di Daerah}

Untuk mensukseskan pelaksanaan otonomi daerah dalam rangka penanggulangan kemiskinan, terdapat enam pilar yang harus dibangun pemerintah daerah, yaitu: 1) pendidikan, 2) pendapatan (ekonomi), 3) kesehatan, 4) hukum, 5) infrastruktur pelayanan publik, dan 6) kelembagaan. Pendidikan dapat dikategorikan sebagai kebutuhan dasar masyarakat yang harus dipenuhi oleh pemerintah daerah. Komitmen terhadap pendidikan merupakan langkah strategis yang memiliki manfaat jangka panjang. Amandemen UUD ' 45 juga telah mengamanatkan kepada pemerintah untuk mengalokasikan anggaran pendidikan sebesar $20 \%$ dari total anggaran. Tidak bisa dipungkiri bahwa pemerintahan yang maju dan unggul adalah pemerintah yang sangat memperhatikan masalahan pendidikan. Oleh karena itu, agenda penting pemerintah daerah di era otonomi daerah dalam rangka menanggulangi kemiskinan adalah membangun kualitas pendidikan. Dengan memperbaiki kualitas pendidikan di daerah, maka lingkaran setan kemiskinan (the vicious cyrcle of poverty) dapat dipotong. Dampak selanjutnya, kemiskinan di daerah akan terkurangi dan kesejahteraan masyarakat akan meningkat.
Agenda berikutnya adalah meningkatkan pendapatan masyarakat. Agenda ini menjadi tantangan berat bagi pemerintah daerah karena menyangkut ada tidaknya entrepreneurship dalam pemerintah daerah. David Osbome dan Ted Gaebler (1992) memberikan sepuluh prinsip untuk mewirausahakan pemerintahan ${ }^{8}$, yaitu:

1. Pemerintahan katalis (Catalytic Govemment: Steering Rather Than Rowing).

2. Pemerintah milik masyarakat (Community-Owned Govemment: Empowering Rather Than Serving).

3. Pemerintah yang kompetitif (Competitive Govemment: Injecting Competition into Service Delivery).

4. Pemerintah yang digerakkan oleh misi (Mission-Driven Government: Transforming Rule-Driven Organizations).

5. Pemerintah yang berorientasi hasil (Results-Oriented Government: Funding Outcomes, Not Inputs).

6. Pemerintah berorientasi pada pelanggan (Customer-Driven Govemment: Meeting the Needs of the Customer, Not the Bureaucracy).

7. Pemerintahan wirausaha (Enterprising Government: Earning Rather Than Spending).

8. Pemerintah antisipatif (Anticipatory Government: Prevention Rather Than Cure).

9. Pemerintah desentralisasi (Decentralized Government: From Hierarchy to Participation and Teamwork).

10. Pemerintah berorientasi pada (mekanisme) pasar (Market-Oriented Government: Leveraging Change Through the Market).

${ }^{8}$ David Osborne dan Ted Gaebler (1992) Reinventing Govemment: How the Entrepreneurial Spint is Transforming the Public Sector, New York: Penguins Books. 
Munculnya gerakan New Public Management ${ }^{\ominus}$ di negara-negara maju, terutama di Eropa, juga telah mendorong pemerintah untuk mengadopsi praktik dan gaya manajemen sektor bisnis ke dalam sektor publik. Praktik dan gaya manajemen sektor bisnis yang perlu diadopsi oleh sektor publik tersebut juga terkait dengan entrepreneurship dalam pemerintahan. Apabila entrepreneurial government dilakukan, maka akan terjadi pergeseran dari state centered menuju market centered. Dari kepemimpinan bergaya militer menjadi bergaya manajer. ${ }^{10}$ Salah satu dampak yang diharapkan dari entrepreneurship dalam pemerintahan daerah adalah meningkatnya pendapatan masyarakat daerah, karena pemerintah dituntut untuk menciptakan pendapatan bukan sekadar membelanjakan atau menghabiskan anggaran (earning rather than spending).

Selain memperbaiki kualitas pendidikan dan meningkatkan pendapatan, pemerintah daerah juga harus memperbaiki kualitas kesehatan masyarakat. Ketiga hal ini, yaitu pendidikan, pendapatan, dan kesehatan merupakan kunci untuk mengatasi masalah kemiskinan di daerah. Kesehatan akan berpengaruh terhadap tingkat produktivitas dan kualitas hidup masyarakat. Untuk itu diperlukan peningkatan jumlah dan kualitas layanan puskesmas, tenaga medis, dan tenaga penyuluh.

Agenda lain yang harus disiapkan pemerintah daerah dalam rangka mensukseskan otonomi daerah adalah perbaikan hukum, infrastruktur publik, dan kelembagaan di daerah. Tanpa ketiga pilar tersebut, maka konsep-konsep pembangunan daerah yang mungkin sangat bagus tidak akan terimplementasikan dengan baik sehingga tidak mencapai tujuan yang diharapkan. Indikator kinerja sektor publik terlihat dari seberapa bagus kualitas pelayanan publik yang diberikan oleh pemerintah. Untuk memberikan kualitas pelayanan publik tersebut diperlukan infrastruktur pelayanan publik yang memadai. Pembangunan infrastruktur pelayanan publik oleh pemerintah daerah perlu ditingkatkan dengan mengacu pada Standar Pelayanan Publik Minimal yang ditetapkan. Untuk dapat memberikan pelayanan publik yang terbaik, perlu didukung oleh profesionalisme kelembagaan di pemerintah daerah dan aturan hukum yang jelas.

\section{Kemitraan Pemerintah Daerah dengan Swasta Dan Sektor Ketiga}

Harus disadari bahwa tidak mungkin seluruh permasalahan pembangunan masyarakat dapat diselesaikan oleh pemerintah daerah sendiri. APBD saja tidak akan mampu mengatasi semua permasalahan daerah. Demikian pula, kemiskinan di daerah tidak akan dapat diatasi oleh pemerintah daerah sendiri melalui APBD. Oleh karena itu, perlu dikembangkan kemitraan antara pemerintah daerah dengan berbagai pihak, baik sektor swasta dan sektor ketiga melalui skema kemitraan pemerintah daerah (local govemment partnership). Pemerintah daerah tidak harus berorientasi untuk meningkatkan volume anggaran setinggi-tingginya, karena

9 New Public Management (NPM) merupakan pendekatan baru dalam manajemen sektor publik yang berupaya menggantikan model administrasi publik tradisional. Gerakan NPM pada awalnya lahir di Inggris tahun 1980an kemudian berkembang di Eropa dan Anglo-Amerika. Saat ini NPM telah menjadi gerakan (issue) global yang dicoba diadopsi oleh berbagai negara.

${ }^{10}$ Lihat juga Mahmudi (2005) Manajemen Kinerja Sektor Publik, Yogyakarta: UPP AMP YKPN. 
yang terpenting bagi pemerintah daerah bukanlah APBD yang besar, tetapi tercapainya kesejahteraan masyarakat.

Yang diperlukan saat ini adalah bagaimana pemerintah daerah mampu mendorong dan menggerakkan sektor swasta dan masyarakat itu sendiri untuk melakukan pembangunan di daerah. Hal itu di samping akan mendorong meningkatnya partisipasi masyarakat dalam pembangunan juga akan menumbuhkembangkan sektor swasta. Dampak selanjutnya adalah meningkatkan perekonomian daerah, perbaikan infrastuktur pelayanan publik, meningkatnya kesejahteraan masyarakat, dan terbentuknya self help community. Pembangunan infrastruktur publik tidak harus dilakukan oleh pemerintah sendiri melalui APBD, tetapi dapat melibatkan pihak swasta.

Untuk mengoptimalkan kemitraan pemerintah daerah dengan sektor swasta dan sektor ketiga diperlukan beberapa syarat yang harus dipenuhi oleh pemerintah daerah. Pertama, diperlukan kemampuan bernegosiasi (negotiation skill) dari aparatur pemerintah daerah, terutama manajer puncak. Kedua, diperlukan komunikasi dan promosi daerah yang agresif dan intensif. Pemerintah daerah dalam hal ini perlu memiliki humas (public relation) yang handal untuk mengenalkan dan mempromosikan daerah kepada investor potensial. Ketiga, untuk menjamin keamanan berinvestasi, pemerintah daerah perlu menciptakan iklim berinvestasi yang baik. Pemerintah daerah harus menjamin dilindunginya hak pribadi (property right), kontrak (contract right), hak karya intelektual (HAKI), menjamin adanya kepastian hukum dan konsistensi kebijakan. Dalam kaitannya dengan pajak daerah, pemerintah daerah dapat memberikan rangsangan berinvestasi berupa pemberian local tax holiday kepada investor.

\section{Pelibatan Usaha Mikro, Kecil, Dan Menengah (UMKM) Dalam Pengadaan Barang Dan Jasa Pemerintah Daerah}

Pengadaan barang dan jasa pada instansi pemerintahan diatur dalam Kepres No. 80 Tahun 2003. Dalam peraturan tersebut diatur ketentuan-ketentuan tentang pengadaan barang dan jasa, baik untuk pemerintah pusat maupun daerah. Melalui Kepres No. 80 Tahun 2003 diatur bahwa pengadaan barang dan jasa di pemerintah daerah dengan nilai tertentu hendaknya dilakukan melalui mekanisme tender. Memang masih terdapat batasan nilai untuk pengeluaran dalam rangka pengadaan barang daerah dengan jumlah tertentu masih dapat dilakukan dengan cara pengadaan langsung atau penunjukan langsung.

Dengan peraturan yang baru tersebut, sebenarnya terdapat peluang bagi Usaha Mikro, Kecil, dan Menegah (UMKM) di daerah untuk ikut serta dalam pengadaan barang dan jasa di pemerintahan. Pemerintah dapat mengeluarkan peraturan yang memberi peluang kepada UMKM untuk dapat terlibat atau dilibatkan dalam pengadaan barang dan jasa daerah. Selain itu, pemerintah daerah juga dapat menetapkan paket-paket pekerjaan serta ketentuan mengenai kewajiban penggunaan produksi dalam negeri dan perluasan kesempatan usaha bagi usaha mikro, kecil, dan menengah (UMKM) dan koperasi di daerah.

Untuk usaha skala menengah di daerah, pada dasarnya mereka sangat berpeluang untuk ikut serta dalam penawaran pengadaan barang daerah. Sementara, untuk usaha skala mikro dan kecil memang terdapat kendala teknis dan administrasi untuk bisa turut serta dalam proses tender. Namun, usaha mikro dan 
Tantangan dan Peluang.Pemerintah Daerah dalam...; Fadel Muhammad \& Mahmudi

kecil masih memungkinkan terlibat dalam pengadaan barang daerah melalui pengadaan atau penunjukan langsung. Kendala UMKM dalam pengadaan barang daerah pada umumnya berupa kendala teknis-administrasi, dan kualitas. Namun dengan adanya proses tender, ada peluang bagi UMKM untuk belajar berkompetesi dan menghasilkan produk yang berkualitas.

Meskipun pemerintah daerah harus berkomitmen untukmembantumengembangkan UMKM, tetapi tidak berarti pemerintah harus selalu memberi fasilitas kepada UMKM. Pemerintah daerah dalam hal ini tetap wajib melaksanakan ketentuan prosestenderyang fair (compulsory competitive terdering) ${ }^{11}$, agar tidak tejadi kebocoran anggaran dan KKN (korupsi, kolusi, dan nepotisme) dalam pengadaan barang darjasadaerah. Untukmenghindaritender berbau KKN yang melibatkan UMKM di daerah, diperlukan sosialisasi kepada UMKM tentang berbagaimekanisme pengadaan barang danjasa daerah, proses tender dan ketentuan teknis administrasinya.

Keterlibatan UMKM dalam pengadaan barang dan jasa daerah pada dasamya tidak hanya untuk pengadaan barang dan jasa yang dibiayai APBD, namun juga termasuk yang dibiayai dari dana hibah dan bantuan lembaga asing. Upaya pelibatan UMKM dalam pengadaan barang dan jasa daerah memiliki dua arti strategis, yaitu: pertama, langkah tersebut sebagai upaya untuk memperkuat pasar lokal yang selama ini menjadi masalah krusial bangsa Indonesia. Masalah utama yang dialami oleh kebanyakan negara berkembang adalah lemahnya pasar lokal, sehingga pelaku ekonomi utama seringkali dipegang oleh etnis tertentu atau pengusaha asing. Kedua, pelibatan UMKM dalam jangka menengah dan panjang akan dapat menurunkan kemiskinan di daerah yang pada akhirnya dapat ikut memperbaiki kesejahteraan masyarakat daerah.

\section{Penutup}

Peran pemerintah daerah dalam penanggulangan kemiskinan dalam konteks otonomi dan desentralisasi fiskal sangat vital. Agenda penting yang harus dilakukan pemerintah daerah dalam rangka mengurangi kemiskinan di daerah adalah mewujudkan demokrasi politik dan demokrasi ekonomi di daerah. Langkah berikutnya adalah membuat kebijakan anggaran yang pro masyarakat miskin. Karena pada kenyataannya kemampuan pemerintah terbatas, dan APBD saja tidaklah mampu untuk menjawab semua permasalahan dan tantangan yang ada, maka pemerintah daerah harus melakukan strategi kemitraan dengan sektor swasta dan sektor ketiga untuk bersama-sama mengetasi kemiskinan di daerah.

\section{Daftar Pustaka}

Cheema, G. S. and Rondinelli, D. A. (Editor) (1983) Decentralization and Development: Policy Implementation in Developing Countries, London: Sage Publications, in cooperation with the United Nations Centre for Regional Development.

"Salah satu prinsip dalam New Public Management adalah perlunya diadopsi mekanisme pasar dalam manajemen sektor publik. Mekanisme kontrak dan tender kompetitif merupakan bentuk dari pengadopsian mekanisme pasar dalam birokrasi: Lebih lanjut lihat Hughes, O. E. (1998) Public Management and Administration, 2nd Ed., London: MacMillan Press Ltd. 
Topik: Keterpaduan Sektor Formal dan Informal Perkotaan

Hughes, O. E. (1998) Public Management and Administration, 2ndEd., London: MacMillan Press Ltd.

Mahmudi (2005) Manajemen Kinerja Sektor Publik, Yogyakarta: UPP AMP YKPN.

Mubyarto (2004) "Ekonomika PasarPopulis," Unisia No. 54/XXVII/IV/2004 (Oktober-Desember).

Muhammad, Fadel (2003) "Dukungan Kelembagaan dan Peraturan Daerah Dalam Pelayanan Publik dan Investasi," Makalah disampaikan pada Seminar Kadinda Makasar.

Osbome, David and Gaebler, T. (1992) Reinventing Government. How the Entrepreneurial Spirit Is Transforming the Public Sector, New York: Penguins Books.
Sabar, Asep (2005) Fadel, Gorontalo dan Sulawesi: Laporan dari Lapangan, Jakarta.

Sen, Amartya (1999) Beyond the Crisis: Development Strategies in Asia, Singapore: Institute of Southeast Asian Studies.

Smith, B. C. (1985) Decentralization the Territorial Dimension of the State, London: George Allen \& Unwin.

Sumodiningrat, Gunawan (2005) Otonomi Daerah Dalam Penanggulangan Kemiskinan:Upaya-Upaya Pengurangan Pengangguran dan Pemberdayaan Usaha Mikro di Tingkat Lokal, Jakarta.

Tussing, A. D. (1975) Poverty in a Dual Economy, New York: ST Martin's Press. 